\title{
Investigation in Nano III-V ternary InxGa1-x $P$ semiconductor materials by chemical vapor deposition
}

\author{
Vedam Ramamurthy ${ }^{1 *}$, Alla Srivani ${ }^{2}$, G Veeraraghavaiah ${ }^{3}$ \\ ${ }^{1}$ Prof and Head of the Department, T.J.P.S College, Guntur, Andhra Pradesh, India \\ ${ }^{2}$ Assistant Professor in Vasi Reddy Venkatadri Institute of Technology (VVIT), \\ Research fellow in IIT KHARAGPUR, Guntur, Andhra Pradesh, India \\ ${ }^{3}$ Assistant professor, P.A.S College, Pedanandipadu, Guntur, Andhra Pradesh, India \\ *Corresponding author E-mail: allasrivani@gmail.com
}

Copyright (c) 2014 Vedam Ramamurthy et al. This is an open access article distributed under the Creative Commons Attribution License, which permits unrestricted use, distribution, and reproduction in any medium, provided the original work is properly cited.

\begin{abstract}
Phosphides of group III have generated important applications in optoelectronic devices. Principally InxGa1-xP is a novel alloy for the development of solid-state lighting and photovoltaic systems, since it is possible to control its band gap from $2.26 \mathrm{eV}$ to $1.27 \mathrm{eV}$ by simply varying the indium concentration. However during the growth of InxGa1-xP inherent defects are obtained in the material, degrading its optical properties. In this work, the effect of the indium concentration is studied. The results of the optical and structural characterization of a series of InxGa1-xP films $(0<\mathrm{x}<$ 0.3 ) deposited by chemical vapor deposition (CVD) are reported.
\end{abstract}

Keywords: Inxgal-Xp, Semiconductor; Luminescence and Optoelectronics.

\section{Introduction}

In the development field of new materials, the compound semiconductors continue being an area of great interest and rapid expansion [1]. The ternary semiconductor $\operatorname{In}_{x} \mathrm{Ga}_{1-\mathrm{x}} \mathrm{P}$ is an important alloy for the development of lighting emitting devices, photovoltaic systems and power electronic, due to the capacity to control the band gap $\left(\mathrm{E}_{g}\right)$, which varies according to the indium concentration in a range of energies from $2.26 \mathrm{eV}$ to $1.27 \mathrm{eV}$ [2]. Recently some at-tempts to grow high-quality low-cost $\operatorname{In}_{\mathrm{x}} \mathrm{Ga}_{1-\mathrm{x}} \mathrm{P}$ have been done. One of the techniques that more likely fulfill the requirements is the chemical vapor deposition (CVD). This technique has reduced the cost of the synthesis maintaining an acceptable level in the optoelectronic properties of $\operatorname{In}_{x} \mathrm{Ga}_{1-\mathrm{x}} \mathrm{P}$. However, the inherent mismatch between the lattice parameters of the sub-strate (sapphire, $\mathrm{SiC}, \mathrm{AsGa}, \mathrm{Si}, \mathrm{LiGaO})$ [3], [4] and the $\mathrm{In}_{\mathrm{x}} \mathrm{Ga}_{1-\mathrm{x}} \mathrm{P}$ phase, plus the indium incorporation $(0<\mathrm{x}<$ 1) limits the growth of the material and degrade the optical and electronic $\mathrm{In}_{x} \mathrm{Ga}_{1-\mathrm{x}} \mathrm{P}$ properties. [5], [6], [8] in this work spectroscopy UV-VIS and photoluminescence (PL) have been used to study the op-tical properties of InGaN films grown by CVD [9]. Scanning electron microscopy and X-ray diffraction were used to char-acterize the morphology and structure of the $\mathrm{In}_{\mathrm{x}} \mathrm{Ga}_{1-\mathrm{x}} \mathrm{P}$ films.

\section{Experimental}

The synthesis of $\operatorname{In}_{x} \mathrm{Ga}_{1-\mathrm{x}} \mathrm{P}$ multilayer films with an indium composition of $0<\mathrm{x}<0.3$ deposited on sapphire at temperature of $900^{ \pm} \mathrm{C}$ were grown by CVD. These films use the layers of Indium Phosphide and gallium Phosphide $(\mathrm{GaP})$ as buffer and nucleation layer, respectively.

The absorption measurements were made by two different techniques: transmission and diffuse reflectance. The absorption spectra were obtained with an AVANTES spectrometer (AvaSpec 256) in the wavelength range from 180 $\mathrm{nm}$ to $1100 \mathrm{~nm}$. The diffuse reflectance was carried out in a UV-visible spectrometer Cary 300. All measurements of absorption were realized at room temperature. The PL measurements were obtained using two different light sources. 
The luminescence of the sample is collimated through a spectrometer (SPECTRAPRO 500i) where Signal is quantified. In the second PL measurement, a UV-visible spectrometer, Hitachi Digilab F4500, with xenon lamp as excitation source was utilized. The XRD characterization was carried out in a powder diffractometer (Philips X'pert). The surface of the $\operatorname{In}_{\mathrm{x}} \mathrm{Ga}_{1-\mathrm{x}} \mathrm{P}$ films was studied in a SEM Jeol 5300 .

\section{Results and discussion}

The absorption results obtained by diffuse reflectance were very different in comparison with the transmission measurements. The attenuation zone (including tails) varies in a region of energies from » $2 \mathrm{eV}$ to $\gg 3.3 \mathrm{eV}(620 \mathrm{~nm}$ to $375 \mathrm{~nm}$ ), which are near to the values of energies band gap expected in the $\operatorname{In}_{\mathrm{x}} \mathrm{Ga}_{1-\mathrm{x}} \mathrm{P}$ films according to the Vegard's law. The origin of these absorption tails are attributed to the deformation of the crystalline lattice and to the existence of defects such as oxygen impurities and gallium/nitrogen vacancies [10].

The samples with indium composition smaller than 20 atomic percent $(x<0: 20)$ showed peaks with a FWHM of $» 500$ meV whereas samples with higher indium composition $(x>0: 20)$ presented a broader peaks with a FWHM of »1 eV. Therefore, as well as the composition is increased in the $\operatorname{In}_{x} G_{1-x} \mathrm{P}$ phase the band gap energy is modified, show-ing a red-shift of the PL peak and also broader luminescence in the high indium samples. This behavior has its origin in the deformation of the $\operatorname{In}_{x} \mathrm{Ga}_{1-\mathrm{x}} \mathrm{P}$ lattice (stress due indium incorporation and the formation of a wide range of different $\mathrm{In}_{\mathrm{x}} \mathrm{Ga}_{1-\mathrm{x}} \mathrm{P}$ crystals) and the existence of defects (oxygen impurities and gallium/nitrogen vacancies). Furthermore, in some parts of the spectra some modulations were observed due to the interference effect (Fabry-Perot) caused by internal reflections within the multilayer in $\operatorname{In}_{x} \mathrm{Ga}_{1-\mathrm{x}} \mathrm{P}$ [11].

Figure 5 shows the XRD results of the $\operatorname{In}_{x} \mathrm{Ga}_{1-\mathrm{x}} \mathrm{P}$ films. These diffractograms showed a hexagonal crystalline phase (wurzite) for the films. $\operatorname{In}_{\mathrm{x}} \mathrm{Ga}_{1-\mathrm{x}} \mathrm{P}(0002)$ and $\mathrm{GaP}$ (0002) planes are marked. $\mathrm{The} \mathrm{In}_{\mathrm{x}} \mathrm{Ga}_{1-\mathrm{x}} \mathrm{P}$ crystalline phase was correlated with $\mathrm{GaP}$ phase located in the $2 \mu\left(34.56^{ \pm}\right)$position for the crystallographic plane (0002) according to the ICDD crystallographic letters [12]. In Fig. $4 b$ is shown traces of Structural and optical characterization of $i_{x} g_{1-x} p$ nano-structured grown by chemical
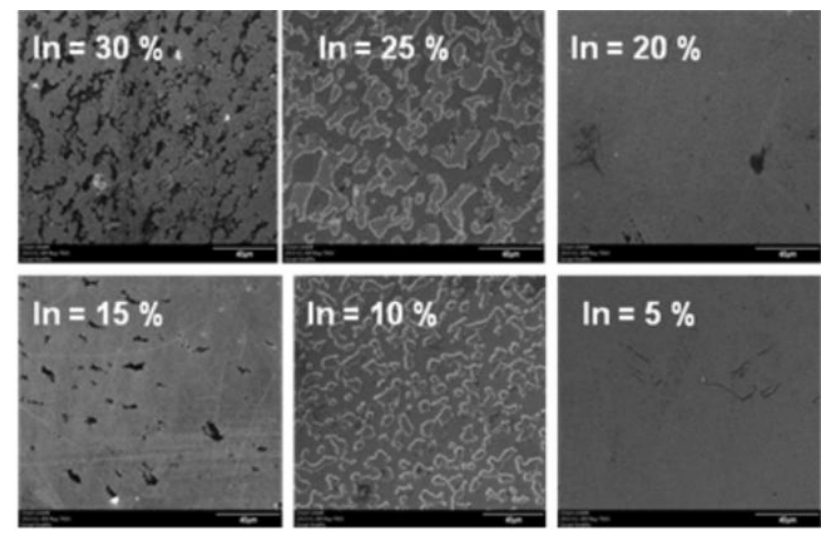

Figure 5 Images of the in $_{\mathrm{x}} \mathrm{ga}_{1-\mathrm{x}} \mathrm{p}$ films surface obtained in the sem. amplification of $750 \mathrm{x}$ and a scale of $40{ }^{I} \mathrm{~m}$. some impurities that appear in the $\mathrm{in}_{\mathrm{x}} \mathrm{ga} \mathrm{a}_{1-\mathrm{x}} \mathrm{p}$ films, in-dium oxide $\left(\mathrm{in}_{2} \mathrm{O}_{3}\right)$, indium phosphide (inp) and indium metal-lic (clusters). The indium oxide can be related with the emission in the $550 \mathrm{~nm}$ region (emission by an indirect transition of 2.09 ev reported by novkovski) [7].

Figure 5 shows SEM images of the $\operatorname{In}_{x} \mathrm{Ga}_{1-\mathrm{x}} \mathrm{P}$ films. The surface morphology of the films does not follow a pattern of growth that has a relation with the indium composition. The growth mode of the $\operatorname{In}_{x} \operatorname{Ga}_{1-x} \mathrm{P}$ films appears to be the Volmer-Weber type. This growth mode is characterized by is-land formation due to nucleation crystals in diverse crystallographic directions. In this case, the crystals are the structures of columnar type which self-ensemble to form $\mathrm{In}_{\mathrm{x}} \mathrm{Ga}_{1-\mathrm{x}} \mathrm{P}$ islands.

\section{Conclusions}

A series of $\operatorname{In}_{x} \mathrm{Ga}_{1-\mathrm{x}} \mathrm{P}$ films deposited by CVD were character-ized. It was found that the $\operatorname{In}_{\mathrm{x}} \mathrm{Ga}_{1-\mathrm{x}} \mathrm{P}$ films with indium composition, $x \cdot 0: 20$ present absorption and emission spec-tra that follow the Vegard's $\operatorname{law} \operatorname{In}_{x} \mathrm{Ga}_{1-\mathrm{x}} \mathrm{P}$ with higher content of indium $(x, 0: 20)$ showed a broad PL emission (FHWM $» 1 \mathrm{eV}$ ) and large tails of absorption. In addition an extrinsic emission in the region of $» 570 \mathrm{~nm}(» 2.17 \mathrm{eV})$ was observed in this films. XRD showed the presence (traces) of undesirable phases such as $\operatorname{In}_{2} \mathrm{O}_{3}, \mathrm{InN}$ and metallic indium in the films. SEM analysis found the formation of $\operatorname{In}_{\mathrm{x}} \mathrm{Ga}_{1-\mathrm{x}} \mathrm{P}$ islands that affect the smoothness of the film surface. 


\section{References}

[1] Ariza C. H, Rev. Acad. Colomb. Cienc., 27 104, (2003), pp. 357-369.

[2] S. Strite and H. Morkoc, American Vaccum Society, B10 4, (1992), pp. 1237-1266.

[3] S. L. Hwang, K. S. Jang, K. H. Kim, H. S. Jeon, H. S. Ahn, M. Yang, Phys. Stat. Sol., 4 1, (2007), pp. 125-128.

[4] M.A. Sanchez' Garcia,' J.L. Pau, F. Naranjo, A. Jimenez,' S. Fernandez,' J. Ristic, F. Calle, E. Calleja y E. Munoz, Material Science and Engineering B, 93 1, (2002), pp. 189-196.

[5] H. J. Chang, C. H. Chen and Y. F. Chen, T.Y. Lin, L. C. Chen, K.H. Chen and Z. H. Lan, Applied physics letters, 86 2, id(021911), (2005), pp. 1-3.

[6] Feng Shih Wei, Tang Tsung-Yi, Lu Yen-Cheng, Liu Shin-Jiun, Lin En-Chiang, Yang C.C., Ma Kung-Jen, Ching-Hsing, Chen L.C., Kim K.H., Lin J. Y., Jiang H.X., Journal of Applied Physics, 95 10, (2004), pp. 5388-5396.

[7] Novkovski, N., Tanusevski, A., 2008. Origin of the optical ab-sorption of In2O3 thin films in the visible range, Semiconductor Science and Technology, 23 (9), id. (095012), 1-4 pp.

[8] Michael A. Reshchikov and Hadis Morkoc, Journal of Applied Physics, 97, 061301, (2005), pp 1-95.

[9] M. U. Gonzalez,' J. A. Sanchez'-Gil, Y. Gonzalez' and L. Gonzalez,' E. R. Mendez,' American Vaccum Society, B18 4, (2000), pp. 19801990 .

[10] O. Vigil y R. Zabala, Revista de F'1sica Cubana, 72, (1987), pp. 67-76.

[11] C. Hums, T. Finger, T. Hempel, J. Christen and A. Dadgar, A. Hoffman, A. Krost, Journal of Applied Physics, 101, 033113-1, (2007), pp. 1-4.

[12] ICDD crystallographic letters: In (00-005-0642), In2O3 (00-006-0416), InN (00-050-1239), Al2O3 (00-010-0173), GaN (00-050-0792). 